\title{
Mid-Regional Pro-Adrenomedullin (MR-proADM) as a Biomarker for Sepsis and Septic Shock: Narrative Review
}

\author{
Uğur Önal $^{1}$ (D), Francisco Valenzuela-Sánchez ${ }^{2}$, Kalwaje Eshwara Vandana ${ }^{3, *}$ and Jordi Rello ${ }^{4}$ \\ 1 Department of Infectious Diseases and Clinical Microbiology, Faculty of Medicine, Ege University, \\ 35100 Izmir, Turkey; ugur.onal@ege.edu.tr \\ 2 Critical Care Medicine Department, University Hospital of Jerez, 11407 Jerez de la Frontera, Spain; \\ pacovaes@yahoo.es \\ 3 Department of Microbiology, Kasturba Medical College, Manipal Academy of Higher Education, \\ Manipal 576104, India \\ 4 Vall d'Hebron Institut of Research, CIBERES, 08035 Barcelona, Spain; jrello@crips.es \\ * Correspondence: vandanake@gmail.com; Tel.: +91-990-220-6009
}

Received: 30 May 2018; Accepted: 29 August 2018; Published: 3 September 2018

\begin{abstract}
Early identification and diagnosis of sepsis and septic shock is vitally important; despite appropriate management, mortality and morbidity rates remain high. For this reason, many biomarkers and screening systems have been investigated in accordance with the precision medicine concept. A narrative review was conducted to assess the role of mid-regional pro-adrenomedullin (MR-proADM) as a biomarker for sepsis and septic shock. Relevant studies were collected via an electronic PubMed, Web of Science, and The Cochrane Library search. The review focused on both diagnosis and prognosis in patients with sepsis and septic shock and specifically in subpopulations of patients with sepsis and septic shock with burns or malignant tumors. No exclusion criteria regarding age, sex, intensive care unit admission, follow-up duration, or co morbidities were used so as to maximize sensitivity and due to lack of randomized controlled trials, opinion paper and reviews were also included in this review. A total of 22 studies, one opinion paper, and one review paper were investigated. MR-proADM levels were found to be useful in assessing patients' initial evolution and become even more useful during follow-up with increased area under curve values in the mortality prognosis by exceeding values of 0.8 in the data shown in several studies. These results also improve along with other biomarkers or severity scores and especially correlate with the organ failure degree. The results of this study indicate that MR-proADM is a good biomarker for the diagnosis and prognosis of sepsis and septic shock patients as well as for organ failure. Although several publications have discussed its role as a biomarker for pneumonia, its value as a biomarker for sepsis and septic shock should now be assessed in randomized controlled trials and more collaborative prospective studies with larger patient samples.
\end{abstract}

Keywords: mid-regional pro-adrenomedullin (MR-proADM); sepsis; septic shock

\section{Introduction}

Adrenomedullin (ADM) plays an important role in the inflammation process and in progression from sepsis to septic shock. Secreted from various organs and tissues, it is mainly produced by vascular endothelial cells and plays a part in vasodilator, positive inotropic, diuretic, natriuretic, and bronchodilator functions [1,2]. Because of the rapid clearance of circulating ADM from the circulation and its binding protein (complement factor $\mathrm{H}$ ), it is difficult to detect plasma ADM levels 
by standard immunoassay. The mid-regional fragment of pro-adrenomedullin (MR-proADM) is more stable and demonstrates the levels of the active ADM peptide [3].

Sepsis and septic shock remain a major healthcare problem worldwide, with high mortality rates. Early identification is vital for reducing these rates [4]. For this reason, many biomarkers and screening systems have been investigated in accordance with the precision medicine concept [5].

Despite the fact that the sepsis and septic shock definitions were updated and severe sepsis with systemic inflammatory response syndrome criteria have been passed out of use according to the third international consensus (Sepsis-3), sepsis is defined as organ dysfunction caused by dysregulated response of a host to an infection and the sequential organ failure assessment (SOFA) score scale has been approved for use in defining organ dysfunction. However, this scale has some limitations because several parameters need to be assessed and cut off points were established for intensive care unit patients [6]. Although there is no golden standard biomarker for sepsis and septic shock patients in terms of diagnosis and prognosis at present, MR-proADM seems to be a good alternative for SOFA score for the assessment of organ failure as well as for predicting mortality of septic patients.

In this paper, we review the role of MR-proADM as a biomarker for sepsis and septic shock. Our hypothesis was that MR-proADM may be a prognostic marker of severity in septic patients and has an important role to play in the initial evaluation and the clinical management of this condition.

\section{Materials and Methods}

We conducted a literature review to investigate the role of MR-proADM in sepsis and septic shock, applying the methodology described below.

\subsection{Information Sources}

An electronic PubMed, Web of Science, and The Cochrane Library search was performed.

\subsection{Search}

The search was performed using the following strategy and key words: mid-regional pro-adrenomedullin [Title/Abstract] OR MR-proADM [Title/Abstract] AND septic shock [Title/Abstract] OR mid-regional pro-adrenomedullin [Title/Abstract] OR MR-proADM [Title/Abstract] AND sepsis [Title/Abstract].

\subsection{Study Selection}

Although new definitions of sepsis and septic shock are available [6], in the interests of comprehensiveness we also included the clinical criteria or confirmed diagnosis for sepsis, severe sepsis, and septic shock [7]. The three target conditions of interest for this review are defined as sepsis, severe sepsis, or septic shock. No exclusion criteria regarding age, sex, intensive care unit admission, follow-up duration, or co morbidities were imposed.

\subsection{Data Items}

We extracted data onto a study-specific pro forma, which included the following list of clinical questions under the PICO framework (Population-Intervention-Comparison-Outcome) format (Table 1). MR-proADM was identified as a diagnostic and prognostic marker, stratifying the mortality risk in septic patients. The measure of the index test as MR-proADM was performed in blood samples. The thresholds used in this review were those generated and presented within each study included, as there is currently no accepted standard; therefore, it was not possible to specify a threshold value beforehand.

\subsection{Risk of Bias in Individual Studies}

Studies were initially selected by the main author (UO), who performed title and abstract screening. We then obtained the full text of each potentially eligible study. 


\subsection{Summary Measures}

Mean and median levels, odd ratios, and $p$ values were stated for each included study, but a meta-analysis could not be performed due to the heterogeneity of the results.

\subsection{Synthesis of Results}

Analysis of all outcomes was performed, including the authors, year of publication, country, study design, total number and classification of patients, and the comparison of MR-proADM with other biomarkers or scoring systems. The results are also sorted by number of patients respectively.

\subsection{Additional Analyses}

The reference lists of all relevant studies were also checked.

\subsection{Study Selection and Characteristics}

A total of 22 studies, one opinion paper, and one review paper were investigated (Table 2).

\subsection{Risk of Bias within Studies}

Two articles were excluded due to the high risk of bias or concerns regarding applicability (using the QUADAS-2 tool) [8]. Additional screening identified one review and one opinion paper with no meta-analyses or randomized controlled trials.

As the study was designed as a narrative literature review, no ethical committee permission was needed. 
Table 1. Population-Intervention-Comparison-Outcome (PICO) Framework.

\begin{tabular}{|c|c|c|c|c|c|c|c|}
\hline \multicolumn{2}{|l|}{ Population } & \multicolumn{3}{|c|}{ Intervention } & Comparison & \multicolumn{2}{|c|}{ Outcome } \\
\hline \multicolumn{2}{|c|}{$\begin{array}{c}\text { In adults (>18 year old) } \\
\text { Patients with sepsis, severe sepsis, or septic shock }\end{array}$} & \multicolumn{3}{|c|}{ Determining of pro-adrenomedullin/MR-proADM levels } & Other biomarkers or score systems & \multicolumn{2}{|c|}{$\begin{array}{l}\text { Assessing of diagnostic or prognostic value (via mortality rates) } \\
\text { of pro-adrenomedullin/MR-proADM levels }\end{array}$} \\
\hline \multicolumn{2}{|c|}{$\begin{array}{c}\text { In children } \\
\text { Patients with sepsis, severe sepsis, or septic shock }\end{array}$} & \multicolumn{3}{|c|}{ Determining of pro-adrenomedullin/MR-proADM levels } & Other biomarkers or score systems & \multicolumn{2}{|c|}{$\begin{array}{l}\text { Assessing of diagnostic or prognostic value (via mortality rates) } \\
\text { of pro-adrenomedullin/MR-proADM levels }\end{array}$} \\
\hline \multicolumn{8}{|c|}{$\begin{array}{l}\text { PCT: procalcitonin; CRP: C-reactive protein; MR-proADM: mid-regional pro-adrenomedullin; TBSA: total body surface area; MR-proANP: mid-regional pro-anti natriuretic peptide; } \\
\text { CT-proET-1: C terminal pro-endothelin 1; PSI: pneumonia severity index; APACHE-II and SOFA (sequential organ failure assessment): score systems. }\end{array}$} \\
\hline Study and Year & Country & Characteristics & No of Patients & Classification of Patients & Comparison & Results & $\begin{array}{l}\text { Sensitivity and Specificity Rates for } \\
\text { MR/ProADM with Cut-Off Levels and } \\
\text { Area Under Curve (AUC) Levels }\end{array}$ \\
\hline \multicolumn{8}{|c|}{ In Adults } \\
\hline Schuetz Ph. et al. TRIAGE study, 2015 & $\begin{array}{l}\text { Switzerland, } \\
\text { France, and USA }\end{array}$ & $\begin{array}{l}\text { Multinational, } \\
\text { prospective, } \\
\text { observational }\end{array}$ & 7132 & $\begin{array}{l}\text { Consecutive medical } \\
\text { patients presenting with a } \\
\text { medical urgency }\end{array}$ & Copeptin, PCT & $\begin{array}{l}\text { For the prediction of death, ProADM } \\
\text { significantly improved regression models, also } \\
\text { improved clinical models for prediction of ICU } \\
\text { admission and high initial treatment urgency }\end{array}$ & $\begin{array}{c}\text { (Cut-off: none mentioned but median } \\
\text { level of proADM in non-survivors: } \\
1.8 \mathrm{nmol} / \mathrm{L} \text { ) } \\
(\text { AUC: } 0.83) \\
\end{array}$ \\
\hline Enguix-Armada A. et al., 2016 & Spain & $\begin{array}{l}\text { Single center, } \\
\text { case-control } \\
\text { cohort }\end{array}$ & 388 & Severe sepsis, septic shock * & $\begin{array}{l}\text { CRP, PCT, presepsin, } \\
\text { and MR-proADM }\end{array}$ & $\begin{array}{l}\text { PCT, MR-proADM, and presepsin are } \\
\text { complementary markers that could be of great } \\
\text { help in the management of septic patients } \\
\text { when they are measured in the first } 24 \mathrm{~h} \text { after } \\
\text { ICU admission }\end{array}$ & $\begin{array}{l}75.8 \% \text { and } 85.9 \% \\
\text { (Cut-off: } 1.11 \mathrm{nmol} / \mathrm{L}) \\
\text { (AUC: } 0.815)\end{array}$ \\
\hline Al Shuaibi M. et al., 2013 & USA & $\begin{array}{l}\text { Single center, } \\
\text { prospective, } \\
\text { observational }\end{array}$ & 340 & $\begin{array}{l}\text { Sepsis, SIRS * with } \\
\text { hematologic malignancies }\end{array}$ & РCT & $\begin{array}{l}\text { ProADM had the advantage of predicting } \\
\text { localized bacterial infection and differentiating } \\
\text { sepsis from SIRS }\end{array}$ & $\begin{array}{l}78 \% \text { and } 35 \% \text { for bloodstream or } \\
\text { localized infections } \\
\text { (Cut-off: } 0.85 \mathrm{nmol} / \mathrm{L} \text { ) } \\
\text { (AUC: } 0.601 \text { ) }\end{array}$ \\
\hline David-Andaluz-Ojeda et al., 2017 & Spain and France & $\begin{array}{l}\text { Two centers, } \\
\text { prospective } \\
\text { observational } \\
\text { cohort }\end{array}$ & 326 & Sepsis or septic shock ${ }^{* * *}$ & PCT, CRP, Lactate & $\begin{array}{l}\text { MR-proADM accuracy to predict mortality is } \\
\text { not affected by the degree of organ failure }\end{array}$ & $\begin{array}{l}83 \% \text { and } 61 \% \text { for SOFA } \leq 6 \\
\text { (Cut-off: } 1.79 \mathrm{nmol} / \mathrm{L}) \\
\text { (AUC: } 0.79)\end{array}$ \\
\hline Angeletti S. et al., 2013 & Italy & $\begin{array}{l}\text { Single center, } \\
\text { case control }\end{array}$ & 320 & Sepsis, severe sepsis, SIRS * & РСТ & $\begin{array}{l}\text { Combined use of PCT and MR-proADM may } \\
\text { substantially improve the early diagnosis } \\
\text { of sepsis }\end{array}$ & $\begin{array}{l}89 \% \text { and } 96.7 \% \\
\text { (Cut-off: } 1 \mathrm{nmol} / \mathrm{L} \text { ) } \\
\text { (AUC: } 0.921 \text { ) }\end{array}$ \\
\hline Angeletti S. et al., 2015 & Italy & $\begin{array}{l}\text { Single center, } \\
\text { retrospective }\end{array}$ & 205 & $\begin{array}{l}\text { Sepsis, severe sepsis, } \\
\text { and septic shock* }\end{array}$ & $\begin{array}{l}\text { PCT, IL-6, IL-10, TNF- } \alpha \text {, } \\
\text { and MCP-1 }\end{array}$ & $\begin{array}{l}\text { The combination of PCT with other markers } \\
\text { should expedite diagnosis and treatment of } \\
\text { sepsis optimizing clinical management }\end{array}$ & $\begin{array}{l}92 \% \text { and } 92 \% \\
\text { (Cut-off: } 1 \text { nmol/L) } \\
\text { (AUC: } 0.950)\end{array}$ \\
\hline Angeletti S. et al., 2015 & Italy & $\begin{array}{l}\text { Single center, } \\
\text { case control }\end{array}$ & 182 & $\begin{array}{l}\text { Sepsis, severe sepsis/septic } \\
\text { shock* }\end{array}$ & РCT & $\begin{array}{l}\text { PCT and MR-proADM combination improved } \\
\text { the diagnosis of bacterial infection and } \\
\text { contributed to prognosis and antibiotic } \\
\text { therapy effectiveness }\end{array}$ & $\begin{array}{l}85.71 \% \text { and } 97.5 \% \\
\text { (Cut-off: } 1.06 \mathrm{nmol} / \mathrm{L}) \\
\text { (AUC: } 0.929)\end{array}$ \\
\hline
\end{tabular}


Table 2. Cont.

\begin{tabular}{|c|c|c|c|c|c|c|c|}
\hline Study and Year & Country & Characteristics & No of Patients & Classification of Patients & Comparison & Results & $\begin{array}{l}\text { Sensitivity and Specificity Rates for } \\
\text { MR/ProADM with Cut-Off Levels and } \\
\text { Area Under Curve (AUC) Levels }\end{array}$ \\
\hline Charles PE. et al., 2017 & France & $\begin{array}{l}\text { Single center, } \\
\text { prospective, } \\
\text { observational }\end{array}$ & 173 & Sepsis, septic Shock * & $\begin{array}{l}\text { PCT, copeptin, } \\
\text { and CT-pro-endothelin } 1 \\
\text { (CT-ProET 1) }\end{array}$ & $\begin{array}{l}\text { MR-ProADM on admission was the best } \\
\text { predictor of short-term clinical outcome if } \\
\text { compared to others and baseline levels and } \\
\text { fluid balance over the 5-day period following } \\
\text { ICU admission were strongly correlated }\end{array}$ & $\begin{array}{l}>80 \% \text { sensitivity rate } \\
\text { (Cut-off: } 5.19 \mathrm{nmol} / \mathrm{L}) \\
\quad(\text { AUC: } 0.75)\end{array}$ \\
\hline Valenzuela-Sanchez F. et al., 2015 & Spain & $\begin{array}{l}\text { Single center, } \\
\text { prospective, } \\
\text { observational }\end{array}$ & 120 & Severe sepsis, SIRS * & PCT, CRP & $\begin{array}{l}\text { Initial MR-proADM levels helped to identify } \\
\text { the infectious origin in patients with SIRS and } \\
\text { organ dysfunction. MR-proADM levels and its } \\
\text { clearance at the 5th day following admission } \\
\text { were the most effective biomarker to } \\
\text { determine unfavorable evolution and the risk } \\
\text { of mortality in patients with severe sepsis } \\
\text { admitted to the ICU }\end{array}$ & $\begin{array}{l}80 \% \text { and } 93.7 \% \\
\text { (Cut-off: } 1.4256 \mathrm{nmol} / \mathrm{L} \text { ) } \\
\text { (AUC: } 0.947 \text { ) }\end{array}$ \\
\hline Travaglino F. et al., 2012 & Italy & $\begin{array}{l}\text { Multicentric, } \\
\text { observational }\end{array}$ & 128 & $\begin{array}{l}\text { Severe infections such as } \\
\text { sepsis * }\end{array}$ & PCT, APACHE-II & $\begin{array}{l}\text { Supporting the prognostic role of } \\
\text { MR-proADM and PCT in that setting, } \\
\text { as demonstrated by the correlation with the } \\
\text { APACHE II score }\end{array}$ & $\begin{array}{l}\text { (AUC: } 0.694 \text { ) } \\
\text { (Cut-off: none mentioned but median } \\
\text { value: } 0.85 \mathrm{nmol} / \mathrm{L} \text { in patient group) }\end{array}$ \\
\hline Debiane L. et al., 2014 & USA & $\begin{array}{l}\text { Single center, } \\
\text { prospective, } \\
\text { cohort }\end{array}$ & 114 & $\begin{array}{l}\text { Critically ill patients with } \\
\text { cancer * }\end{array}$ & PCT, CRP & $\begin{array}{c}\text { In critically ill patients with cancer, } \\
\text { pro-adrenomedullin and PCT both had a } \\
\text { promising role in predicting bloodstream } \\
\text { infections in a manner more helpful than CRP }\end{array}$ & $\begin{array}{l}\text { 67\% and 68\% for blood stream infections } \\
\text { (Cut-off: } 2.2 \text { nmol/L for blood stream } \\
\text { infections) } \\
\text { (AUC: } 0.70)\end{array}$ \\
\hline Christ-Crain M. et al., 2005 & Switzerland & $\begin{array}{l}\text { Single center, } \\
\text { case-control }\end{array}$ & 101 & $\begin{array}{l}\text { SIRS, sepsis, severe sepsis, } \\
\text { and septic shock * }\end{array}$ & $\begin{array}{l}\text { APACHE-II, SAPS-II, } \\
\text { PCT, CRP, IL-6 }\end{array}$ & $\begin{array}{l}\text { Prediction outcome is similar to those of the } \\
\text { APACHE II and the SAPS II scores; } \\
\text { MR-proADM found as a prognostic biomarker } \\
\text { in critically ill patients with different severities } \\
\text { of sepsis }\end{array}$ & $\begin{array}{l}83.3 \% \text { and } 87.8 \% \\
\text { (Cut-off: } 3.9 \mathrm{nmol} / \mathrm{L} \text { ) } \\
\text { (AUC: } 0.81 \text { ) }\end{array}$ \\
\hline De La Torre-Prados MV. et al., 2016 & Spain & $\begin{array}{l}\text { Single center, } \\
\text { prospective, } \\
\text { observational }\end{array}$ & 100 & Septic shock* & $\begin{array}{l}\text { PCT, CRP, lactate, } \\
\text { APACHE-II, SOFA }\end{array}$ & $\begin{array}{l}\text { MR-proADM levels measured on admission } \\
\text { correlated with 28-day mortality in patients } \\
\text { with septic shock }\end{array}$ & $\begin{array}{c}79 \% \text { and } 61 \% \\
\text { (Cut-off: } 1.2 \mathrm{ng} / \mathrm{mL} \text { ) }\end{array}$ \\
\hline Guignant C. et al., 2012 & France & $\begin{array}{l}\text { Single center, } \\
\text { observational }\end{array}$ & 98 & Septic shock* & $\begin{array}{l}\text { C-terminal-provasopressin, } \\
\text { midregional-proatrial } \\
\text { natriuretic peptide, and } \\
\text { C-terminal-proendothelin-1 }\end{array}$ & $\begin{array}{c}\text { Elevated plasmatic MR-proADM } \\
\text { concentration was associated with the } \\
\text { development of secondary nosocomial } \\
\text { infections after septic shock }\end{array}$ & $\begin{array}{c}\text { (Cut-off: none mentioned but mean value: } \\
0.3 \mathrm{nmml} / \mathrm{L}) \\
(\mathrm{AUC:} 0.86)\end{array}$ \\
\hline Schuetz P. et al., 2007 & Switzerland & $\begin{array}{l}\text { Single center, } \\
\text { observational }\end{array}$ & 95 & $\begin{array}{l}\text { SIRS, sepsis, and septic } \\
\text { shock * }\end{array}$ & $\begin{array}{l}\text { PCT, CT-proET-1, } \\
\text { APACHE-II }\end{array}$ & $\begin{array}{l}\text { Endothelin-1 and adrenomedullin precursor } \\
\text { peptides gradually increased with increasing } \\
\text { severities of infection in critically ill patients. }\end{array}$ & $\begin{array}{c}71.4 \% \text { and } 71.6 \% \\
\text { (CT-proET-1(pmol/L)/MR-proADM(nmol/L) } \\
\text { ratio cut-off: } 11 \text { ) } \\
\text { (AUC: } 0.76 \text { for MR-proADM) }\end{array}$ \\
\hline Andaluz-Ojeda et al., 2015 & Spain & $\begin{array}{l}\text { Single center, } \\
\text { cohort }\end{array}$ & 71 & $\begin{array}{l}\text { Severe sepsis and septic } \\
\text { shock * }\end{array}$ & $\begin{array}{l}\text { PCT, CRP, APACHE-II, } \\
\text { SOFA }\end{array}$ & $\begin{array}{l}\text { ProADM was the only biomarker showing } \\
\text { significant differences between survivors and } \\
\text { non-survivors for concentration in plasma in the } \\
\text { three time points (day 1,3, and 7) analyzed. }\end{array}$ & $\begin{array}{l}\text { (Cut-off: } 0.94 \mathrm{nmol} / \mathrm{L} \text { ) } \\
\text { (AUC: } 0.75)\end{array}$ \\
\hline
\end{tabular}


Table 2. Cont.

\begin{tabular}{|c|c|c|c|c|c|c|c|}
\hline Study and Year & Country & Characteristics & No of Patients & Classification of Patients & Comparison & Results & $\begin{array}{l}\text { Sensitivity and Specificity Rates for } \\
\text { MR/ProADM with Cut-Off Levels and } \\
\text { Area Under Curve (AUC) Levels }\end{array}$ \\
\hline Lundberg OH. et al., 2016 & Sweden & $\begin{array}{l}\text { Single center. } \\
\text { cohort }\end{array}$ & 53 & Septic shock* & $\begin{array}{l}\text { MR-proADM, } \\
\text { CT-proET-1, hsTNT, } \\
\text { and left ventricular } \\
\text { systolic functions }\end{array}$ & $\begin{array}{l}\text { Levels of MR-proADM and CT-proET-1 were } \\
\text { significantly higher among patients with } \\
\text { myocardial injury and were correlated with } \\
\text { left ventricular systolic dysfunction. } \\
\text { MR-proADM and hsTNT were significantly } \\
\text { higher among 7-day and 28-day } \\
\text { non-survivors. }\end{array}$ & $\begin{array}{l}80 \% \text { and } 60 \% \\
\text { (Cut-off: } 3.5 \mathrm{nmol} / \mathrm{L} \text { ) } \\
\text { (AUC: } 0.730 \text { ) }\end{array}$ \\
\hline Suberviola B. et al., 2012 & Spain & $\begin{array}{l}\text { Single center, } \\
\text { prospective, } \\
\text { observational }\end{array}$ & 49 & $\begin{array}{l}\text { Severe sepsis, septic shock } \\
\text { due to CAP }\end{array}$ & PCT, CRP, PSI & $\begin{array}{l}\text { MR-proADM levels correlate with increasing } \\
\text { severity of illness and death and offer } \\
\text { additional risk stratification in high-risk CAP } \\
\text { patients }\end{array}$ & $\begin{array}{l}53 \% \text { and } 84 \% \\
\text { (Cut-off: } 4.86 \mathrm{nmmol} / \mathrm{L}) \\
\text { (AUC: } 0.72 \text { ) }\end{array}$ \\
\hline Gille J. et al., 2017 & Germany & $\begin{array}{l}\text { Single center, } \\
\text { prospective, } \\
\text { observational }\end{array}$ & 42 & $\begin{array}{l}\text { Sepsis * (TBSA }>15 \% \\
\text { burned patients) }\end{array}$ & PCT & $\begin{array}{l}\text { PCT displayed higher specificity and } \\
\text { sensitivity, while MR-proADM may be more } \\
\text { suitable for the early recognition of sepsis }\end{array}$ & $\begin{array}{l}63 \% \text { and } 80 \% \\
\text { (Cut-off: } 0.15 \mathrm{nmol} / \mathrm{L} \text { variance) } \\
\text { (AUC: } 0.76 \text { ) }\end{array}$ \\
\hline Pereira J. et al., 2016 & Portugal & $\begin{array}{l}\text { Single center, } \\
\text { prospective, } \\
\text { cohort }\end{array}$ & 19 & Severe CAP* & SAPS-II, SOFA & $\begin{array}{l}\text { In severe CAP patients, a decrease in } \\
\text { MR-proADM serum levels in the first } 48 \mathrm{~h} \\
\text { after ICU admission was a good predictor of } \\
\text { clinical response and better outcome }\end{array}$ & $\begin{array}{l}\text { (Cut-off: none mentioned but with the } \\
\text { percent change of MR-proADM in } \\
48 \text { hours, AUC: } 0.80 \text { for in } \\
\text { hospital mortality) }\end{array}$ \\
\hline \multicolumn{8}{|c|}{ In Children } \\
\hline Miguel D. et al., 2011 & Spain & $\begin{array}{l}\text { Single center, } \\
\text { case control, } \\
\text { prospective } \\
\text { observational }\end{array}$ & 267 & $\begin{array}{l}\text { Newborn infants with or } \\
\text { without risk factors of } \\
\text { sepsis* }\end{array}$ & $\begin{array}{l}\text { CT-proET-1, } \\
\text { MR-proANP, and PCT }\end{array}$ & $\begin{array}{l}\text { The median values (reference interval) of } \\
\text { CT-proET-1, MR-pro-ADM, and MR-proANP } \\
\text { measured in cord blood plasma were } \\
72 \text { pmol/L ( } 39-115), 0.84 \text { nmol/L }(0.5-1.38) \\
\text { and } 163 \mathrm{pmol} / \mathrm{L}(76-389) \text {, respectively }\end{array}$ & $\begin{array}{l}\text { Reference range for MR-proADM: } \\
0.55 \text { to } 1.38 \mathrm{nmol} / \mathrm{L}\end{array}$ \\
\hline Rey C. et al., 2013 & Spain & $\begin{array}{l}\text { Two centers, } \\
\text { prospective } \\
\text { observational }\end{array}$ & 254 & Critically ill children * & $\begin{array}{l}\text { CT-proET-1, PCT, } \\
\text { and CRP }\end{array}$ & $\begin{array}{l}\text { In critically ill children, high levels of } \\
\text { MR-proADM, CT-proET-1, and PCT were } \\
\text { associated with increased prediction of } \\
\text { mortality risk scores }\end{array}$ & $\begin{array}{l}93 \% \text { and } 76 \% \\
\text { (Cut-off: } 0.79 \mathrm{nmol} / \mathrm{L} \text { ) } \\
\text { (AUC: } 0.87 \text { ) }\end{array}$ \\
\hline \multicolumn{8}{|c|}{ Opinion Paper } \\
\hline Di Somma S. et al., 2013 & Italy & Opinion paper & - & Sepsis & $\begin{array}{l}\text { PCT, inducible protein } \\
10 \text { (IP10), Group IV } \\
\text { phospholipase A2 type } \\
\text { II (PLA2 II), neutrophil } \\
\text { gelatinase-associated } \\
\text { lipocalin (NGAL), } \\
\text { natriuretic peptides, } \\
\text { mature adrenomedullin } \\
\text { (ADM), copeptin, } \\
\text { thrombopoietin, Mer } \\
\text { receptor, and red blood } \\
\text { cell distribution } \\
\text { width (RDW) }\end{array}$ & $\begin{array}{l}\text { Biomarkers including MR-proADM can } \\
\text { represent an appealing perspective in the } \\
\text { diagnosis and management of patients with } \\
\text { sepsis. Nevertheless, at the moment, it is not } \\
\text { still clear if it is better to use a multimarkers } \\
\text { approach or if a single, most appropriate, } \\
\text { biomarker exists }\end{array}$ & \\
\hline
\end{tabular}


Table 2. Cont.

\begin{tabular}{|c|c|c|c|c|c|c|c|}
\hline Study and Year & Country & Characteristics & No of Patients & Classification of Patients & Comparison & Results & $\begin{array}{l}\text { Sensitivity and Specificity Rates for } \\
\text { MR/ProADM with Cut-Off Levels and } \\
\text { Area Under Curve (AUC) Levels }\end{array}$ \\
\hline \multicolumn{8}{|c|}{ Review } \\
\hline Valenzuela Sanchez F. et al., 2016 & Spain & Review & - & Sepsis, septic shock & CRP, PCT & $\begin{array}{l}\text { The MR-proADM levels are more effective } \\
\text { than procalcitonin (PCT) and C-reactive } \\
\text { protein (CRP) levels to determine an } \\
\text { unfavorable outcome and the risk of mortality } \\
\text { in patients with sepsis admitted to the ICU. } \\
\text { It has also proved useful in patients diagnosed } \\
\text { with organ dysfunction of infectious etiology }\end{array}$ & \\
\hline
\end{tabular}

ICU: intensive care unit; SIRS: systemic inflammatory response syndrome; IL: interleukin; TNF: tumor necrosis factor; MCP: monocyte chemoattractant protein; SAPS: simplified acute

physiology score; hsTNT: high sensitivity troponin T; CAP: community acquired pneumonia; PCT: procalcitonin; CRP: C-reactive protein; MR-proADM: mid-regional pro-adrenomedullin;

TBSA: total body surface area; PSI: pneumonia severity index; APACHE-II and SOFA: score systems; AUC: area under the receiver operating characteristic curve. * American College of

Chest Physicians/Society of Critical Care Medicine Consensus Conference and Surviving Sepsis Campaign Criteria. ${ }^{* *}$ SEPSIS-3 Criteria. 


\section{Results}

\subsection{Usefulness of MR-ProADM as Biomarker for Diagnosis and Prognosis in Sepsis}

Several biomarkers have been investigated for early diagnosis of sepsis $[9,10]$. In the literature, MR-proADM has mainly been associated with pulmonary infections [11-16].

A multinational, prospective, observational cohort study named TRIAGE included a total number of 7132 patients with medical emergencies shows that for the prediction of death, ProADM significantly improved regression models, also improved clinical models for prediction of intensive care unit admission and high initial treatment urgency [17].

Enguix-Armada et al. analyzed 388 patients to determine whether the combination of C-reactive protein (CRP), procalcitonin (PCT), presepsin, or SCD14-ST and MR-proADM measured in the first $24 \mathrm{~h}$ after intensive care unit (ICU) admission improved diagnostic and prognostic management in both severe sepsis and septic shock. They found that MR-proADM showed a better prognostic value $(p<0.001)$ particularly in cases of septic shock $(p<0.01)$, increasing in line with the APACHE-II score [18].

In the study by Andaluz-Ojeda et al. 326 patients with severe sepsis (21.7\%) or septic shock (79.3\%) were assessed in order to compare biomarkers (CRP, PCT, lactate, and MR-proADM) for septic patients with different degrees of organ failure (via SOFA scores). MR proADM was the only biomarker to predict mortality in all severity groups (SOFA $\leq 6$, SOFA $=7-12$, and SOFA $\geq 13$ ) with AUROC (area under receiver operator characteristic) (95\% CI (confidence interval) of 0.75 (0.61-0.88), 0.74 (0.66-0.83), and $0.73(0.59-0.86)$, respectively $(p<0.05)$; the best AUROC was for mortality prediction at 28 days in the analysis over the entire cohort (AUROC (95\% CI) $0.79(0.74-0.84))(p<0.001)$ [19].

Recently, Charles et al. published a prospective cohort study of 173 septic patients admitted to ICU in order to evaluate the prognostic values of PCT, (MR-proADM, copeptin, and CT-pro-endothelin 1 (CT-ProET 1) concentrations. The best AUROC values on day one were obtained with MR-ProADM and the CT-proET-1/MR-proADM ratio (0.75 (0.67-0.85) and 0.82 (0.75-0.89); 95\% CI respectively). In addition, baseline MR-proADM levels and fluid balance over the five-day period following the admission of ICU were strongly correlated (Rho $=0.41 ; p<0.001)$ [20].

In a cohort of 128 patients referred to the emergency department with high fever and suspected severe infections such as sepsis, lower respiratory tract infections, urinary tract infections, gastrointestinal infections, soft tissue infections, central nervous system infections, or osteomyelitis, Travaglino et al. found a correlation in the sepsis-septic shock groups between the APACHE II score and MR-proADM [21]. Investigating 120 patients, Valenzuela Sanchez et al. concluded that initial MR-proADM levels helped to identify the infectious origin in patients with systemic inflammatory response syndrome (SIRS) and organ dysfunction [22]. MR-proADM levels and its clearance on day 5 after admission were the most effective biomarkers for determining unfavorable evolution and the risk of mortality in patients with severe sepsis admitted to the ICU [22].

In 2005, Christ-Crain et al.'s observational study of MR-proADM as a prognostic marker in sepsis in 101 patients proposed its use as a new prognostic biomarker in critically ill patients with varying severities of sepsis. The ability of MR-proADM to predict outcomes was similar to that of APACHE II and SAPS II scores [23]. De la Torre-Prados et al. found that MR-proADM showed the best association with 28-day mortality and also had prognostic value (log rank test: $p=0.001)$. Statistical significance was also seen in the Cox regression analysis $(p<0.001)$ for 100 patients with a relative risk 1.26 times higher than baseline for each mmol/L of increase in MR-proADM [24].

In 71 patients with severe sepsis and septic shock, Andaluz-Ojeda et al. also concluded that proADM was the only biomarker to show significant differences between survivors and non-survivors for concentration in plasma at the three time points analyzed (day 1, 3, and 7); it was the biomarker with the best diagnostic accuracy for predicting mortality in the ICU in the AUROC analysis [25]. In 48 septic patients (15 of whom had septic shock), Schuetz et al. found mean MR-proADM levels at admission to be below $1 \mathrm{nmol} / \mathrm{L}$ in non-septic critical patients, $2.6 \mathrm{nmol} / \mathrm{L}$ in patients with 
sepsis, and $8 \mathrm{nmol} / \mathrm{L}(p<0.01)$ in patients with septic shock [26]. Lundberg et al. also showed that MR-proADM and high sensitivity troponin T (hsTNT) levels were significantly higher among 7-day and 28-day non-survivors [27].

In critically ill children, Rey et al. found that MR-proADM, CT-proET-1, and PCT concentrations above $0.80 \mathrm{nmol} / \mathrm{L}, 123 \mathrm{pmol} / \mathrm{L}$ and $2 \mathrm{ng} / \mathrm{mL}$, respectively, could be used by clinicians to identify those at higher risk of death [28]. Miguel et al. also defined the following reference intervals for potential sepsis markers among newborn infants measured in cord blood plasma with or without risk factors of sepsis: CT-proET-1: $72 \mathrm{pmol} / \mathrm{L}$ (39-115); MR-pro-ADM: $0.84 \mathrm{nmol} / \mathrm{L}$ (0.5-1.38); and MR-proANP: 163 pmol/L (76-389) [29].

\subsection{MR-proADM Levels and Sepsis in Burn Patients}

Burns are also associated with increased levels of MR-proADM, but the dynamics regarding sepsis onset after burn injury need to be studied in greater depth. Assessing PCT and MR-proADM as biomarkers of sepsis in 42 burn patients with $>15 \%$ total body surface area, Gille et al. found that in the patients who developed sepsis $(n=27,64.3 \%)$ MR-proADM and PCT levels were significantly higher $(p<0.001)$ on days categorized as septic, with an increase of $31 \%$ and at least $0.015 \mathrm{nmol} / \mathrm{L}$ (area under curve 0.76 ) or of $>39 \%$ and at least $0.15 \mu \mathrm{g} / \mathrm{L}$ (area under the curve 0.83 ), respectively, for the detection of sepsis. Interestingly, the increase in MR-proADM was recorded one day earlier than in PCT, so the authors concluded that it may be more suitable for use in early recognition of sepsis [30].

\subsection{MR-proADM Levels in Sepsis with Underlying Malignancies}

In malignancies, the origin of fever should be distinguished from infectious and non-infectious causes, such as tumor burden, blood transfusions, or medications. Biomarkers have also been investigated for the diagnosis of infection [31]. Al Shuaibi et al. studied 340 febrile patients (103 with definite sepsis, and 159 with systemic inflammatory response syndrome, SIRS) with hematologic malignancies for the presence of sepsis, SIRS, documented infections, and response to antimicrobial therapy. Only initial MR-proADM levels were found to be significantly higher in patients with localized bacterial infections than in those with no documented infection $(p=0.019)$ and significantly higher in patients with definite sepsis than in those with SIRS $(p=0.023)$ [32].

Debiane et al. also investigated the utility of biomarkers as predictors of sepsis and blood stream infections in 114 febrile critically ill patients with cancer ( 55 hematologic malignancy, 59 solid tumor). They found that AUROCs for bloodstream infection diagnosis were significantly higher for MR-proADM $(0.70 ; 95 \%$ CI, 0.59-0.82) and PCT $(0.71 ; 95 \%$ CI, 0.60-0.83) than for CRP $(0.53$; $95 \%$ CI, 0.39-0.66) ( $p=0.021$ and $p=0.003$, respectively). With regard to patients' response to antimicrobial therapy, MR-proADM, PCT, and CRP levels all decreased significantly from baseline to follow-up in responders $(p=0.002)$, while only MR-proADM increased significantly in non-responders $(p<0.001)[33]$.

\section{Discussion}

In septic patients, early diagnosis and stratification or triage is vitally important for the initiation of appropriate treatment. Our review provides new information on the diagnostic and prognostic role of MR-proADM in sepsis and septic shock.

Statistical analysis could not be performed due to the heterogeneity of the results. In order to define the exact role of MR-proADM as a biomarker for sepsis and septic shock, randomized controlled trials and more collaborative prospective studies should be performed with large numbers of patients.

Due to the complex structure of the septic response, a combination of several tests is likely to be more effective for diagnosis and management than a single ideal biomarker. Angeletti et al. investigated the combined measurement of biomarkers in 104 patients with sepsis and found a better post-test probability with the combination of PCT with MR-proADM; the combination of PCT, MR-proADM, and TNF- $\alpha$ showed the best result in the early diagnosis of sepsis [34]. In both 
sepsis and localized infections, Angeletti et al. found that the combined use of PCT and MR-proADM increased the post-test probability of diagnosing bacterial infections compared to PCT alone [35].

Although PCT levels are affected by the pathogen (for example, high levels for Gram-negative sepsis), levels of MR-proADM seem to be related to the degree of organ failure and severity of infection rather than the causative agent such as the bacterium or yeast [36]. Angeletti et al. investigated 200 patients with sepsis according to source (Gram-positive and Gram-negative, yeast, and polymicrobial); the AUC for MR-proADM for each were $0.96(p<0.01), 0.94(p<0.001), 0.99$ $(p<0.001)$, and $0.98(p<0.001)$, respectively [37].

MR-proADM levels for viral infections as the source of sepsis and septic shock have not been previously studied. However, Valenzuela-Sanchez et al. reported that MR-proADM plasma levels measured in influenza A pneumonia without bacterial co-infection were more useful than PCT or CRP for predicting the risk of mortality and need for mechanical ventilation [38,39]. In addition, Guignant et al. found significantly elevated plasma MR-proADM concentrations in patients who developed nosocomial infections after a septic shock episode $(p=0.043)$ [40]. Thus, the follow-up of MR-proADM levels may represent a major breakthrough in the monitoring of infectious risk in the ICU patient.

MR-proADM levels are also useful in assessing patients' evolution. PCT levels may normalize even though the severity persists, and MR-proADM becomes even more useful during evolution, with increased AUROC values in the mortality prognosis by exceeding values of 0.8 in the data shown in several studies. The results also improve along with other biomarkers or severity scores $[19,20,22,27,32,33,40]$.

Our review has some limitations. First of all, the studies present data from high income or developed countries. In low- and middle-income countries, due to lack of resources, diagnosis and triage of sepsis should be performed prior to hospital admission; therefore, physical examination plays an important role [41]. In a study of African countries, Baelani et al. found that $37 \%$ did not have the capability to measure lactate [42]. Secondly, the source of sepsis should be considered for the diagnosis and management. The studies published differentiate between the bacterial sources of sepsis and septic shock, but bacteria are not the only causative pathogens: MR-proADM should also be investigated in fungal, viral, and parasitic infections. Although some randomized controlled trials and meta-analyses of the role of MR-proADM in predicting severity and outcome in community-acquired pneumonia patients have been published in order to define the exact role of MR-proADM as a biomarker for sepsis and septic shock, we recommend the performance of randomized controlled trials and more collaborative prospective studies with large numbers of patients specifically in this group of patients [11,43]. Overall, regarding the role of MR-proADM in sepsis and septic shock patients, this review corroborates a prior report which stressed its importance in combination with other biomarkers or organ failure score systems in accordance with the concept of precision medicine [44,45]. A recent systematic review and meta-analysis that assessed both ADM and MR-proADM in patients with sepsis found that the AUC for sROC (summary receiver operating characteristic) was 0.80 (95\% CI, 0.77-0.84), which was greater than the results of published meta-analyses of procalcitonin, troponin, and lactate clearance [46]. Finally, the systematic literature review ended in July 2017 and this is an active area of research.

In spite of these limitations, this article has research implications for the future. Perhaps the most interesting value of MR-proADM in sepsis does not lie in its isolated prognostic value (according to the different studies, the molecule presents a modest AUROC that ranges between 0.7 and 0.8 for mortality) or in its diagnostic role (currently poorly demonstrated) but in the combination with other severity scales (such as the risk of early admission to intensive care unit (REA-ICU) score, PSI, CURB-65, SOFA, or APACHE II scores). In this way, many authors have shown how using a combination of the biomarker plus several scales has significantly improved the prognostic value of the first in the field of pneumonia and sepsis. Recent work by Angeletti et al., Andaluz Ojeda et al., and Spoto $S$ et al. demonstrate the interesting potential of the molecule in this aspect $[19,34,47]$. Finally, identifying drug-response phenotypes is a priority. As emphasized by a recent ESCMID position paper towards precision medicine in sepsis, when searching for biomarkers it is essential to assess their clinical 
utility [48]. Investigators need to identify biomarkers that are more or less likely to respond to specific interventions (predictive markers).

\section{Conclusions}

MR-proADM has been identified as a prognostic marker that is able to stratify the mortality risk in sepsis patients with different degrees of organ failure. It may be helpful in the early identification and individual risk assessment of sepsis and may also facilitate the subsequent clinical management of sepsis and septic shock. Due to the complex structure of the septic response, it is likely that a combination of several tests may be more effective for diagnosis and management than a single ideal biomarker. MR-proADM levels may also be useful for diagnosis or prognosis of sepsis and septic shock in patients with malignancy or in burn patients.

Author Contributions: Conceptualization, U.O. and J.R.; Methodology, U.O.; Validation, U.O., J.R., F.V.-S. and K.E.V.; Formal Analysis, U.O., J.R. and F.V.-S.; Investigation, U.O. and F.V.-S.; Resources, U.O.; Data Curation, U.O. and F.V.-S.; Writing-Original Draft Preparation, U.O., J.R., F.V.-S. and K.E.V.; Writing-Review \& Editing, U.O., J.R. and F.V.-S.; Visualization, U.O.; Supervision, J.R.; Project Administration, J.R.; Corresponding Author, K.E.V.

Funding: This research was supported in part by CIBERES, Fondos FEDER, Institudo de Salud Carlos III; Madrid, Spain and an Observership Grant from the European Society of Clinical Microbiology and Infectious Diseases, Basel, Switzerland.

Acknowledgments: We thank Sonia Uriona and Magda Campins, Barcelona, Spain for methodological advice and critical review and support; to Mike Maudley for the english edition of the manuscript.

Conflicts of Interest: Jordi Rello has received research grants from Thermo Fisher. Francisco Valenzuela-Sánchez has received research grants from Thermo Fisher. Other authors declare no conflict of interest. The funders had no role in the design of the study; in the collection, analyses, or interpretation of data; in the writing of the manuscript, and in the decision to publish the results.

\section{References}

1. Kitamura, K.; Kangawa, K.; Eto, T. Adrenomedullin and PAMP: Discovery, Structures, and Cardiovascular Functions. Microsc. Res. Tech. 2002, 57, 3-13. [CrossRef] [PubMed]

2. Brain, S.D. Vascular Actions of Calcitonin Gene-Related Peptide and Adrenomedullin. Physiol. Rev. 2004, 84, 903-934. [CrossRef] [PubMed]

3. Struck, J.; Tao, C.; Morgenthaler, N.G.; Bergmann, A. Identification of an Adrenomedullin Precursor Fragment in Plasma of Sepsis Patients. Peptides 2004, 25, 1369-1372. [CrossRef] [PubMed]

4. Herrán-Monge, R.; Muriel-Bombín, A.; García-García, M.M.; Merino-García, P.A.; Cítores-González, R.; Fernández-Ratero, J.A.; Albalá, N.; Carriedo, D.; Moradillo-González, S.; Álvarez-Martínez, B.; et al. Mortality Reduction and Long-Term Compliance with Surviving Sepsis Campaign: A Nationwide Multicenter Study. Shock 2016, 45, 598-606. [CrossRef] [PubMed]

5. Zhang, Z.; Smischney, N.J.; Zhang, H.; Van Poucke, S.; Tsirigotis, P.; Rello, J.; Honore, P.M.; Kuan, W.S.; Ray, J.J.; Zhou, J.; et al. AME Evidence Series 001-the Society for Translational Medicine: Clinical Practice Guidelines for Diagnosis and Early Identification of Sepsis in the Hospital. J. Thorac. Dis. 2016, 8, 2654-2665. [CrossRef] [PubMed]

6. Singer, M.; Deutschman, C.S.; Seymour, C.; Shankar-Hari, M.; Annane, D.; Bauer, M.; Bellomo, R.; Bernard, G.R.; Chiche, J.D.; Coopersmith, C.M.; et al. The Third International Consensus Definitions for Sepsis and Septic Shock (Sepsis-3). JAMA 2016, 315, 801-810. [CrossRef] [PubMed]

7. Dellinger, R.; Levy, M.; Rhodes, A. Surviving Sepsis Campaign: International Guidelines for Management of Severe Sepsis and Septic Shock, 2012. Crit. Care Med. 2013, 41, 580-637. [CrossRef] [PubMed]

8. Whiting, P.F.; Rutjes, A.W.S.; Westwood, M.E.; Mallett, S.; Deeks, J.J.; Reitsma, J.B.; Leeflang, M.M.G.; Sterne, J.A.C.; Bossuyt, P.M.M. QUADAS-2: A Revised Tool for the Quality Assessment of Diagnostic Accuracy Studies. Ann. Intern. Med. 2011, 155, 529-536. [CrossRef] [PubMed]

9. Surani, S.; Varon, J. Biomarkers in the early recognition of sepsis: The quest continues. Am. J. Emerg. Med. 2015, 33, 1671. [CrossRef] [PubMed] 
10. Di Somma, S.; Magrini, L.; Travaglino, F.; Lalle, I.; Fiotti, N.; Cervellin, G.; Avanzi, G.C.; Lupia, E.; Maisel, A.; Hein, F.; et al. Opinion Paper on Innovative Approach of Biomarkers for Infectious Diseases and Sepsis Management in the Emergency Department. Clin. Chem. Lab. Med. 2013, 51, 1167-1175. [CrossRef] [PubMed]

11. Liu, D.; Xie, L.; Zhao, H.; Liu, X.; Cao, J. Prognostic Value of Mid-Regional pro-Adrenomedullin (MR-proADM) in Patients with Community-Acquired Pneumonia: A Systematic Review and Meta-Analysis. BMC Infect. Dis. 2016, 16, 232. [CrossRef] [PubMed]

12. Huang, D.T.; Angus, D.C.; Kellum, J.A.; Pugh, N.A.; Weissfeld, L.A.; Struck, J.; Delude, R.L.; Rosengart, M.R.; Yealy, D.M. Midregional Proadrenomedullin as a Prognostic Tool in Community-Acquired Pneumonia. Chest 2009, 136, 823-831. [CrossRef] [PubMed]

13. Pereira, J.M.; Azevedo, A.; Basilio, C.; Sousa-Dias, C.; Mergulhao, P.; Paiva, J.A. Mid-Regional Proadrenomedullin: An Early Marker of Response in Critically Ill Patients with Severe Community-Acquired Pneumonia? Rev. Port. Pneumol. 2016, 22, 308-314. [CrossRef] [PubMed]

14. Suberviola, B.; Castellanos-Ortega, A.; Llorca, J.; Ortiz, F.; Iglesias, D.; Prieto, B. Prognostic Value of Proadrenomedullin in Severe Sepsis and Septic Shock Patients with Community-Acquired Pneumonia. Swiss Med. Wkly. 2012, 142, w13542. [CrossRef] [PubMed]

15. Christ-Crain, M.; Opal, S.M. Clinical Review: The Role of Biomarkers in the Diagnosis and Management of Community-Acquired Pneumonia. Crit. Care 2010, 14, 203. [CrossRef] [PubMed]

16. Courtais, C.; Kuster, N.; Dupuy, A.-M.; Folschveiller, M.; Jreige, R.; Bargnoux, A.-S.; Guiot, J.; Lefebvre, S.; Cristol, J.-P.; Sebbane, M. Proadrenomedullin, a Useful Tool for Risk Stratification in High Pneumonia Severity Index Score Community Acquired Pneumonia. Am. J. Emerg. Med. 2013, 31, 215-221. [CrossRef] [PubMed]

17. Schuetz, P.; Hausfater, P.; Amin, D.; Amin, A.; Haubitz, S.; Faessler, L.; Kutz, A.; Conca, A.; Reutlinger, B.; Canavaggio, P.; et al. Biomarkers from Distinct Biological Pathways Improve Early Risk Stratification in Medical Emergency Patients: The Multinational, Prospective, Observational TRIAGE Study. Crit. Care 2015, 19, 377. [CrossRef] [PubMed]

18. Enguix-Armada, A.; Escobar-Conesa, R.; De La Torre, A.G.; De La Torre-Prados, M.V. Usefulness of Several Biomarkers in the Management of Septic Patients: C-Reactive Protein, Procalcitonin, Presepsin and Mid-Regional pro-Adrenomedullin. Clin. Chem. Lab. Med. 2016, 54, 163-168. [CrossRef] [PubMed]

19. Andaluz-Ojeda, D.; Nguyen, H.B.; Meunier-Beillard, N.; Cicuéndez, R.; Quenot, J.P.; Calvo, D.; Dargent, A.; Zarca, E.; Andrés, C.; Nogales, L.; et al. Superior Accuracy of Mid-Regional Proadrenomedullin for Mortality Prediction in Sepsis with Varying Levels of Illness Severity. Ann. Intensive Care 2017, 7, 15. [CrossRef] [PubMed]

20. Charles, P.E.; Péju, E.; Dantec, A.; Bruyère, R.; Meunier-Beillard, N.; Dargent, A.; Prin, S.; Wilson, D.; Quenot, J.P. Mr-Proadm Elevation upon Icu Admission Predicts the Outcome of Septic Patients and Is Correlated with Upcoming Fluid Overload. Shock 2017, 48, 418-426. [CrossRef] [PubMed]

21. Travaglino, F.; De Berardinis, B.; Magrini, L.; Bongiovanni, C.; Candelli, M.; Silveri, N.G.; Legramante, J.; Galante, A.; Salerno, G.; Cardelli, P.; et al. Utility of Procalcitonin (PCT) and Mid Regional pro-Adrenomedullin (MR-proADM) in Risk Stratification of Critically Ill Febrile Patients in Emergency Department (ED). A Comparison with APACHE II Score. BMC Infect. Dis. 2012, 12, 184. [CrossRef] [PubMed]

22. Valenzuela Sanchez, F.; Valenzuela Mendez, B.; Bohollo de Austria, R.; Rodríguez Gutierrez, J.; Jaen Franco, M.; González García, M.; Jareño Chaumel, A. Diagnostic and Prognostic Usefulness of Mid-Regional pro-Adrenomedullin Levels in Patients with Severe Sepsis. Intensive Care Med. Exp. 2015, 3 (Suppl. 1), A306. [CrossRef]

23. Christ-Crain, M.; Morgenthaler, N.G.; Struck, J.; Harbarth, S.; Bergmann, A.; Müller, B. Mid-Regional pro-Adrenomedullin as a Prognostic Marker in Sepsis: An Observational Study. Crit. Care 2005, 9, R816-R824. [CrossRef] [PubMed]

24. DE LA Torre-Prados, M.V.; Garcia-DE LA Torre, A.; Enguix, A.; Mayor-Reyes, M.; Nieto-Gonzalez, M.; Garcia-Alcantara, A. Mid-Regional pro-Adrenomedullin as Prognostic Biomarker in Septic Shock. Minerva Anestesiol. 2016, 82, 760-766. [PubMed]

25. Andaluz-Ojeda, D.; Cicuéndez, R.; Calvo, D.; Largo, E.; Nogales, L.; Muñoz, M.F.; Bueno, P.; Eiros, J.M.; Gandía, F.; Bermejo-Martín, J.F. Sustained Value of Proadrenomedullin as Mortality Predictor in Severe Sepsis. J. Infect. 2015, 71, 136-139. [CrossRef] [PubMed]

26. Schuetz, P.; Christ-Crain, M.; Morgenthaler, N.G.; Struck, J.; Bergmann, A.; Müller, B. Circulating Precursor Levels of Endothelin-1 and Adrenomedullin, Two Endothelium-Derived, Counteracting Substances, in Sepsis. Endothel. J. Endothel. Cell Res. 2007, 14, 345-351. [CrossRef] [PubMed] 
27. Lundberg, O.H.M.; Bergenzaun, L.; Rydén, J.; Rosenqvist, M.; Melander, O.; Chew, M.S. Adrenomedullin and Endothelin-1 Are Associated with Myocardial Injury and Death in Septic Shock Patients. Crit. Care 2016, 20, 178. [CrossRef] [PubMed]

28. Rey, C.; García-Hernández, I.; Concha, A.; Martínez-Camblor, P.; Botrán, M.; Medina, A.; Prieto, B.; López-Herce, J. Pro-Adrenomedullin, pro-Endothelin-1, Procalcitonin, C-Reactive Protein and Mortality Risk in Critically Ill Children: A Prospective Study. Crit. Care 2013, 17, R240. [CrossRef] [PubMed]

29. Miguel, D.; Prieto, B.; Costa, M.; Coto, D.; Alvarez, F.V. Cord Blood Plasma Reference Intervals for Potential Sepsis Markers: Pro-Adrenomedullin, pro-Endothelin, and pro-Atrial Natriuretic Peptide. Clin. Biochem. 2011, 44, 337-341. [CrossRef] [PubMed]

30. Gille, J.; Ostermann, H.; Dragu, A.; Sablotzki, A. MR-proADM: A New Biomarker for Early Diagnosis of Sepsis in Burned Patients. J. Burn Care Res. 2017, 38, 290-298. [CrossRef] [PubMed]

31. Limper, M.; de Kruif, M.D.; Duits, A.J.; Brandjes, D.P.M.; van Gorp, E.C.M. The Diagnostic Role of Procalcitonin and Other Biomarkers in Discriminating Infectious from Non-Infectious Fever. J. Infect. 2010, 60, 409-416. [CrossRef] [PubMed]

32. Al Shuaibi, M.; Bahu, R.R.; Chaftari, A.M.; Al Wohoush, I.; Shomali, W.; Jiang, Y.; Debiane, L.; Raad, S.; Jabbour, J.; Al Akhrass, F.; et al. Pro-Adrenomedullin as a Novel Biomarker for Predicting Infections and Response to Antimicrobials in Febrile Patients with Hematologic Malignancies. Clin. Infect. Dis. 2013, 56, 943-950. [CrossRef] [PubMed]

33. Debiane, L.; Hachem, R.Y.; Al Wohoush, I.; Shomali, W.; Bahu, R.R.; Jiang, Y.; Chaftari, A.M.; Jabbour, J.; Al Shuaibi, M.; Hanania, A.; et al. The Utility of Proadrenomedullin and Procalcitonin in Comparison to C-Reactive Protein as Predictors of Sepsis and Bloodstream Infections in Critically Ill Patients with Cancer. Crit. Care Med. 2014, 42, 2500-2507. [CrossRef] [PubMed]

34. Angeletti, S.; Dicuonzo, G.; Fioravanti, M.; De Cesaris, M.; Fogolari, M.; Lo Presti, A.; Ciccozzi, M.; De Florio, L. Procalcitonin, MR-Proadrenomedullin, and Cytokines Measurement in Sepsis Diagnosis: Advantages from Test Combination. Dis. Markers 2015, 2015, 951532. [CrossRef] [PubMed]

35. Angeletti, S.; Spoto, S.; Fogolari, M.; Cortigiani, M.; Fioravanti, M.; De Florio, L.; Curcio, B.; Cavalieri, D.; Costantino, S.; Dicuonzo, G. Diagnostic and Prognostic Role of Procalcitonin (PCT) and MR-pro-Adrenomedullin (MR-proADM) in Bacterial Infections. APMIS 2015, 123, 740-748. [CrossRef] [PubMed]

36. Jeong, S.; Park, Y.; Cho, Y.; Kim, H.S. Diagnostic Utilities of Procalcitonin and C-Reactive Protein for the Prediction of Bacteremia Determined by Blood Culture. Clin. Chim. Acta 2012, 413, 1731-1736. [CrossRef] [PubMed]

37. Angeletti, S.; Battistoni, F.; Fioravanti, M.; Bernardini, S.; Dicuonzo, G. Procalcitonin and Mid-Regional pro-Adrenomedullin Test Combination in Sepsis Diagnosis. Clin. Chem. Lab. Med. 2013, 51, 1059-1067. [CrossRef] [PubMed]

38. Valenzuela Sanchez, F.; Valenzuela Mendez, B.; Rodríguez Gutierrez, J.F.; Bohollo De Austria, R.; Rubio Quiñones, J.; Puget Martínez, L.; Valiente Alemán, I.; Estella García, A. Initial Levels of Mr-Proadrenomedullin: A Predictor of Severity in Patients with Influenza a Virus Pneumonia. Intensive Care Med. Exp. 2015, 3 (Suppl. 1), 1-2. [CrossRef]

39. Valenzuela-Sanchez, F.; Valenzuela-Mendez, B.; Rodriguez-Gutierrez, J.F.; Rello, J. Personalized Medicine in Severe Influenza. Eur. J. Clin. Microbiol. Infect. Dis. 2016, 35, 893-897. [CrossRef] [PubMed]

40. Guignant, C.; Voirin, N.; Venet, F.; Lepape, A.; Monneret, G. Persistent High Level of Circulating Midregional-Proadrenomedullin and Increased Risk of Nosocomial Infections after Septic Shock. J. Trauma Acute Care Surg. 2012, 72, 293-296. [CrossRef] [PubMed]

41. Rello, J.; Leblebicioglu, H. Sepsis and Septic Shock in Low-Income and Middle-Income Countries: Need for a Different Paradigm. Int. J. Infect. Dis. 2016, 48, 120-122. [CrossRef] [PubMed]

42. Baelani, I.; Jochberger, S.; Laimer, T.; Otieno, D.; Kabutu, J.; Wilson, I.; Baker, T.; Dünser, M.W. Availability of Critical Care Resources to Treat Patients with Severe Sepsis or Septic Shock in Africa: A Self-Reported, Continent-Wide Survey of Anaesthesia Providers. Crit. Care 2011, 15, R10. [CrossRef] [PubMed]

43. Christ-Crain, M.; Morgenthaler, N.G.; Stolz, D.; Müller, C.; Bingisser, R.; Harbarth, S.; Tamm, M.; Struck, J.; Bergmann, A.; Müller, B. Pro-Adrenomedullin to Predict Severity and Outcome in Community-Acquired Pneumonia [ISRCTN04176397]. Crit. Care 2006, 10, R96. [CrossRef] [PubMed]

44. Valenzuela-Sánchez, F.; Valenzuela-Méndez, B.; Rodríguez-Gutiérrez, J.F.; Estella-García, Á.; González-García, M.Á. New Role of Biomarkers: Mid-Regional pro-Adrenomedullin, the Biomarker of Organ Failure. Ann. Transl. Med. 2016, 4, 329. [CrossRef] [PubMed] 
45. Elke, G.; Bloos, F.; Wilson, D.C.; Brunkhorst, F.M.; Briegel, J.; Reinhart, K.; Loeffler, M.; Kluge, S.; Nierhaus, A.; Jaschinski, U.; et al. The Use of Mid-Regional Proadrenomedullin to Identify Disease Severity and Treatment Response to Sepsis-A Secondary Analysis of a Large Randomised Controlled Trial. Crit. Care 2018, 22, 79. [CrossRef] [PubMed]

46. Li, Q.; Wang, B.S.; Yang, L.; Peng, C.; Ma, L.B.; Chai, C. Assessment of Adrenomedullin and Proadrenomedullin as Predictors of Mortality in Septic Patients: A Systematic Review and Meta-Analysis. Med. Intensiva 2017. [CrossRef] [PubMed]

47. Spoto, S.; Cella, E.; de Cesaris, M.; Locorriere, L.; Mazzaroppi, S.; Nobile, E.; Lanotte, A.M.; Pedicino, L.; Fogolari, M.; Costantino, S.; et al. Procalcitonin and Mr-Proadrenomedullin Combination with Sofa and Qsofa Scores for Sepsis Diagnosis and Prognosis: A Diagnostic Algorithm. Shock 2018, 50, 44-52. [CrossRef] [PubMed]

48. Rello, J.; van Engelen, T.S.R.; Alp, E.; Calandra, T.; Cattoir, V.; Kern, W.V.; Netea, M.G.; Nseir, S.; Opal, S.M.; van de Veerdonk, F.L.; et al. Towards Precision Medicine in Sepsis: A Position Paper from the European Society of Clinical Microbiology and Infectious Diseases. Clin. Microbiol. Infect. 2018. [CrossRef] [PubMed]

(C) 2018 by the authors. Licensee MDPI, Basel, Switzerland. This article is an open access article distributed under the terms and conditions of the Creative Commons Attribution (CC BY) license (http:// creativecommons.org/licenses/by/4.0/). 